\title{
Approaches to formalization of the informal waste sector into municipal solid waste management systems in low- and middle-income countries: Review of barriers and success factors
}

\author{
Aparcana Robles, Sandra Roxana
}

Published in:

Waste Management

Link to article, DOI:

10.1016/j.wasman.2016.12.028

Publication date:

2016

Document Version

Peer reviewed version

Link back to DTU Orbit

Citation (APA):

Aparcana Robles, S. R. (2016). Approaches to formalization of the informal waste sector into municipal solid waste management systems in low- and middle-income countries: Review of barriers and success factors.

Waste Management, 61, 593-607. https://doi.org/10.1016/j.wasman.2016.12.028

\section{General rights}

Copyright and moral rights for the publications made accessible in the public portal are retained by the authors and/or other copyright owners and it is a condition of accessing publications that users recognise and abide by the legal requirements associated with these rights.

- Users may download and print one copy of any publication from the public portal for the purpose of private study or research.

- You may not further distribute the material or use it for any profit-making activity or commercial gain

- You may freely distribute the URL identifying the publication in the public portal 


\title{
Approaches to formalization of the informal waste sector into municipal solid waste management systems in low- and middle-income countries: Review of barriers and success factors
}

\author{
Sandra Aparcana \\ UNEP DTU Partnership, Department of Management Engineering, Technical University of Denmark, Marmorvej 51, 2100 København Ø, Denmark
}

\section{A R T I C L E I N F O}

\section{Article history:}

Received 12 April 2016

Revised 17 November 2016

Accepted 17 December 2016

Available online $\mathrm{xxxx}$

\section{Keywords:}

Municipal solid waste management

Formalization

Informal waste sector

Low-and middle-income countries

\begin{abstract}
A B S T R A C T
Background and goal: The Municipal Solid Waste Management (MSWM) sector represents a major challenge for low-and middle-income countries due to significant environmental and socioeconomic issues involving rapid urbanization, their MSWM systems, and the existence of the informal waste sector. Recognizing its role, several countries have implemented various formalization measures, aiming to address the social problems linked to this sector. However, regardless of these initiatives, not all attempts at formalization have proved successful due to the existence of barriers preventing their implementation in the long term. Along with this, there is a frequent lack of knowledge or understanding regarding these barriers and the kind of measures that may enable formalization, thereby attaining a win-win situation for all the stakeholders involved. In this context, policy- and decision-makers in the public and private sectors are frequently confronted with the dilemma of finding workable approaches to formalization, adjusted to their particular MSWM contexts.

Building on the review of frequently implemented approaches to formalization, including an analysis of the barriers to and enabling measures for formalization, this paper aims to address this gap by explaining to policy- and decision-makers, and to waste managers in the private sector, certain dynamics that can be observed and that should be taken into account when designing formalization strategies that are adapted to their particular socioeconomic and political-institutional context. This includes possible links between formalization approaches and barriers, the kinds of barriers that need to be removed, and enabling measures leading to successful formalization in the long term.

Method: This paper involved a literature review of common approaches to formalization, which were classified into three categories: (1) informal waste workers organized in associations or cooperatives; (2) organized in CBOs or MSEs; and (3) contracted as individual workers by the formal waste sector. This was followed by the identification and subsequent classification of measures for removing common barriers to formalization into five categories: policy/legal, institutional/organizational, technical, social, and economic/financial. The approaches to formalization, as well as the barrier categories, were validated through the assessment of twenty case studies of formalization. Building on the assessment, the paper discussed possible links between formalization approaches and barriers, the 'persistent' challenges that represent barriers to formalization, as well as key enabling factors improving the likelihood of successful formalization.

Results: Regardless of the type of approach adopted to formalization, the review identifies measures to remove barriers in all five categories, with a stronger link between the approaches 1 and 2 and the existence of measures in the policy, institutional, and financial categories. Regarding persistent barriers, the review identified ones arising from the absence of measures to address a particular issue before formalization or due to specific country- or sector-related conditions, and their interaction with the MSWM context. $75 \%$ of the case studies had persistent barriers in respect of policy/legal issues, $50 \%$ of institutional/ organizational, $45 \%$ of financial/economic, and $40 \%$, and $35 \%$ of social and technical issues respectively. Conclusions: This paper concludes that independently of the formalization approach, the lack of interventions or measures in any of the five categories of barriers may lead formalization initiatives to fail, as unaddressed barriers become 'persistent' after formalization is implemented. Furthermore, 'persistent barriers' may also appear due to unfavorable country-specific conditions. The success of a formalization initiative does not depend on a specific approach, but most likely on the inclusion of country-appropriate
\end{abstract}

E-mail address: sanapa@dtu.dk 
measures at the policy, economic and institutional levels. The empowerment of informal waste-workers is again confirmed as a further key success factor for their formalization.

(C) 2016 Elsevier Ltd. All rights reserved.

\section{Contents}

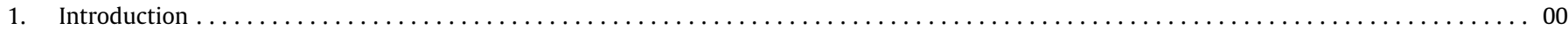

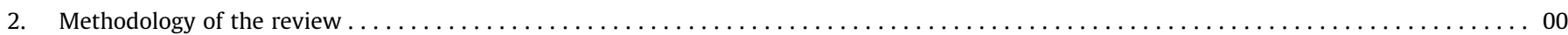

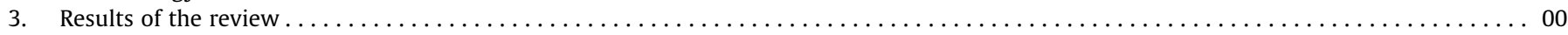

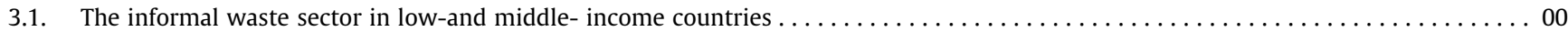

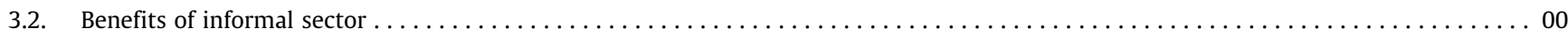

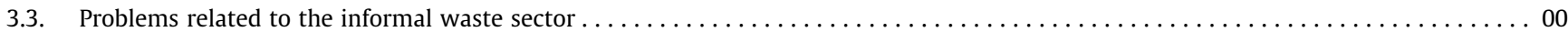

3.4. Current policies and waste governance regarding the informal sector $\ldots \ldots \ldots \ldots$

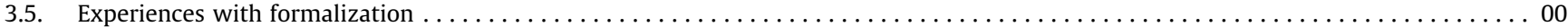

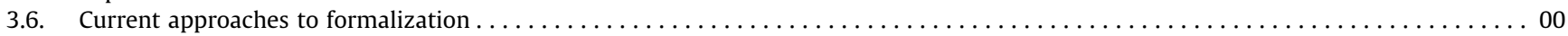

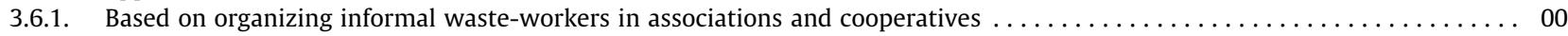

3.6.2. Based on organizing recyclers in CBOs (Community Based Organizations) or MSEs (Micro- and Small Enterprises) . . . . . . . 00

3.6.3. Based on adopting informal waste-workers as workers for the formal waste management sector .............. 00

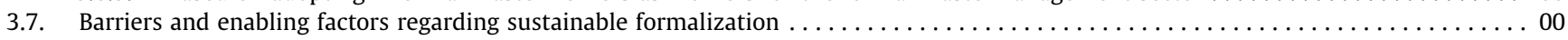

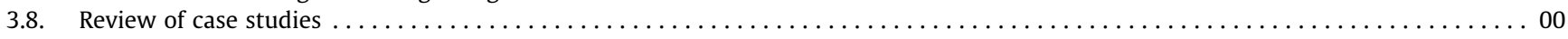

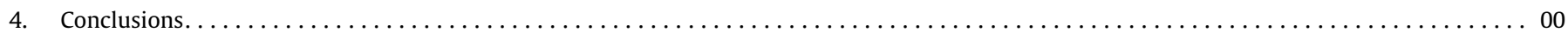

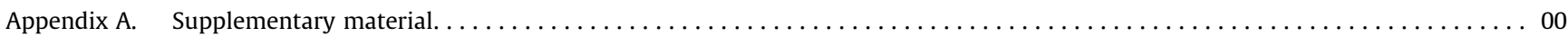

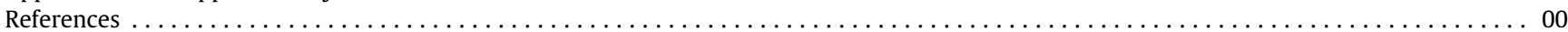

\section{Introduction}

Managing municipal solid waste is a big challenge. Inappropriate municipal solid waste management not only causes critical environmental impacts (climate change, environmental and human health damage, biodiversity loss, soil erosion) (Hoornweg and Bhada-Tata, 2012; Cleary, 2009), it also has negative economic and social impacts (Cointreau, 2006; Scheinberg et al. 2010; Lohri et al., 2014). The challenge is greater in low-and middle-income countries, which share several similarities regarding their socioeconomic conditions, in particular in having waste management systems that operate to low standards (Wilson et al., 2006, cited by Aparcana et al. 2012; Hoornweg and Bhada-Tata, 2012).

This situation creates the need for alternative ways to handle and dispose of the waste, which has led to the emergence of informal waste activities (called the 'informal waste sector'). The informal sector contributes significantly to the recycling rates of many cities in low-and middle-income countries, thus reducing the volume of waste deposited in landfills, environmental pollution, creating at the same time local added value through the recycling market and informal employment opportunities (Scheinberg et al., 2010; Wilson et al., 2012). However, despite these benefits, the informal sector is also associated with negative social and economic conditions, such as poverty, bad working conditions, exploitation, discrimination, child labor, social rejection, and lack of education (Wilson et al., 2006; Medina, 2000).

In light of this situation, policy-and decision makers have identified the need to recognize the contribution of the informal sector, while improving their working conditions and socioeconomic situation. For this reason, a variety of formalization approaches have been devised and implemented in recent years. However, the road to successful formalization is not always free of difficulties. Policyand decision-makers, as well as waste managers in the private waste sector face a variety of barriers to formalization, when designing formalization approaches according to their specific country contexts. There is a lack of understanding regarding the type of barriers arising before and after formalization, the possible measures to eliminate those barriers in the long term, and the options to structure these enabling measures as formalization strategies. As a result, decision-makers may decide to copy the "modernization" trends applied in high-income countries (Scheinberg et al., 2006; Gutberlet, 2011) or formalization experiences from other countries, without considering the potential differences between their MSWM systems and the situations in those countries, nor the interaction with the informal sector.

The purpose of this paper is to shed light on policy- and decision-makers, and to waste managers in the private sector on the aspects that should be taken into account when designing formalization strategies, including the types of barriers that may be encountered before and after formalization and the enabling measures adopted to address them. Furthermore, it is expected to provide further insights regarding approaches to formalization, associated barriers, and enabling measures; answering the question of whether the occurrence of certain barriers is linked to specific approaches to formalization, or not.

The current paper starts by providing general background information about the informal waste sector in low-and middle income countries, social issues and waste governance towards the informal sector. This is followed by a review of different approaches to formalization, including a categorization of common barriers to formalization. This is subsequently validated through a review of twenty case studies, which are grouped according to their approach to formalization. The barrier categories are used as the criteria for identifying enabling measures applied by the selected cases, towards the elimination of barriers. Based on this assessment, this paper discusses how the enabling measures were conceptualized and combined in each formalization approach, as well as their effectiveness. Furthermore, it identifies the 'persistent' barriers that remained as 'challenges' to be overcome by formalized MSWM systems, and discusses the feasibility of their removal.

\section{Methodology of the review}

The study involved a literature review looking at common formalization approaches that have been implemented in low-and 
middle-income countries. Based on this, the approaches to formalization were classified according their tendencies to establish organizational structures and in accordance with other characteristics. The paper continued with a literature-based research for the identification and subsequent classification of typical barriers to formalization, as well as measures for removing them.

The approaches to formalization and the barrier categories were validated through the review of twenty case studies, which were selected based on the organizational structures implemented in the formalization processes, the availability of information in public secondary sources, and their geographical location (covering Africa, Asia, and South America). The paper analyzed and discussed their common characteristics, according to the type of formalization approach applied, types of barriers encountered before and after formalization, the enabling measures applied, and the outcomes. Building on this, the review identified problems that represent 'persistent' barriers that remain after formalization, as well as discusses key enabling factors that may remove them in the long term. The supplementary material in this paper provides a summarized description of the case studies.

\section{Results of the review}

\subsection{The informal waste sector in low-and middle- income countries}

The informal waste sector consists of individuals, groups and micro-enterprises performing informal waste services and/or informal valorization "but are not sponsored, financed, recognized or allowed by the formal solid waste authorities, or who operate in violation of or in competition with formal authorities" (Scheinberg et al., 2010, cited by Velis et al., 2012). Their main motivation is to earn an income through service fees or by selling valuable materials extracted from waste (Gunsilius et al., 2011a).

These individuals or groups are known by many names, depending on the local language, but they are usually known as recyclers, scavengers, waste-pickers or rag-pickers (Gutberlet, 2011; Medina, 2000; Wilson et al., 2006). Different informal sector activities have been observed in low-and middle-income countries: itinerant waste-buyers, who go from door to door and collect and buy recyclable materials; street waste-pickers, who recover recyclable materials from mixed waste on the streets; municipal waste collection crews, who recover recyclable materials while transporting them to disposal sites; and finally waste-picking at dumping places. After picking and sorting, informal wasteworkers sell the recyclable materials to earn a livelihood (Scheinberg et al., 2006).

Downstream in the value chain are the middlemen or informal traders/small junkshops. Typically, small traders buy collected recyclable materials from the informal waste-workers and sell the materials to recycling processors companies As a general rule, the junk shops disappoint the informal waste-workers by paying them very low prices for the materials, as they capacity of adding value to the collected secondary materials is limited (Wilson et al., 2006).

Despite being socially marginalized and working under poor conditions, informal waste-workers contribute significantly to recycling rates in low-and middle-income countries. As a result of an extensive literature review, Linzner and Lange (2013) report informal recycling rates of up to $45 \%$ of the generated waste (in some cases even more), while Linzer and Salhofer (2014) estimate informal recycling rates of between $17 \%$ and $38 \%$ of the municipal solid waste generated in urban China. Furthermore, Wilson et al. (2012) report that in Bamako, Mali, the informal sector carries out up to almost $100 \%$ of total recycling activities. Other cities with an important presence on the part of the informal sector are
Quezon City (Philippines), Varna (Bulgaria), Delhi (India), Managua (Nicaragua) and Dhaka (Bangladesh).

\subsection{Benefits of informal sector}

The positive contribution of the informal sector is also reflected through the financial contribution they make to the formal waste management sector. Several studies point to the cost reductions to formal waste management systems as a direct consequence of the informal waste activities. The quantity of waste that the formal sector has to collect is significantly reduced, which means lower labor, transport and infrastructure costs. Also, landfilling is optimized through the reduction of volume use (Wilson et al., 2006). As reported in an assessment of six cities carried out by Gunsilius et al. (2011b), informal collection and recycling contribute to the high avoided costs related to waste collection amounting to 14 million EUR/year in Lima (Peru), 12 million EUR/year in Cairo (Egypt) and 3.4 million EUR/year in Quezon City (Philippines). In Lusaka (Zambia) the net cost of informal waste collection is only $1.6 \mathrm{USD} /$ ton, or $10.4 \mathrm{USD} /$ ton less than in the formal sector. UNEP (2010) mentions the cases of Jakarta, Delhi and Bangalore, where informal recycling prevents around 30\% (in Jakarta) and $15 \%$ of waste going to landfill (Delhi and Bangalore). Informal recycling represents savings on waste collection and disposal costs of around 13,700 USD/day for the Delhi and Bangalore municipalities. Regarding job creation, Linzner and Lange (2013) estimate that informal waste management systems generate between ten and forty times more jobs than systems in a highincome country.

\subsection{Problems related to the informal waste sector}

Despite the positive economic and environmental impacts of the informal waste sector, several studies have also identified serious social problems, such as poor working and living conditions, child labor, school absences and incomplete school education for adults (Medina, 2000; Wilson et al., 2006; Scheinberg et al., 2006 and ILO, 2004). Frequently, informal waste activities involve families working with their children, who can be found picking in the streets or working at dump sites (ILO, 2004; Scheinberg et al., 2006). The main factors driving child labor are their economic contribution to their families through unpaid work, family poverty, a lack of skills and educational opportunities, and the high costs of schooling, among other things (ILO, 2004). Another main issued is health. Informal waste-workers work without protective clothing or equipment, being more likely to be injured by sharp objects (needles, broken glass, metal, etc.) and animals (dog bites, rat bites, etc.) (UNEP, 2005). Further studies have reported increased risk of musculoskeletal problems (Cointreau, 2006), ophthalmological and respiratory infections (UNEP; 2005), and work-related respiratory gastrointestinal and skin problems Rushton (2003). Exacerbating this situation is the lack of water and sanitation infrastructure for informal waste-workers and their families, who often live in poor areas close to dump sites (Cointreau, 2006).

Citizens, as well as the authorities, are often hostile to informal waste-workers (Medina 2000). They generally suffer the social stigma of being associated with waste. Informal waste-workers are often subjected to harassment by officials, exploited by middlemen and despised by society generally, and it is hard to find citizens who appreciate their work, or partners at the political and legal levels who are prepared to defend their interests (Gunsilius et al., 2011a). Nas and Jaffe (2004) point out the attitude of selfhatred and lack of self-confidence adopted by informal wasteworkers, who consider themselves to be associated with 'subhuman characteristics'. However, this self-perception may vary depending on their position in the value change. Individual 
waste-workers are more vulnerable due to their not having an organized supportive network, being more exposed to exploitation, social rejection, etc. (Wilson et al., 2006). Scheinberg and Savain (2015) present the case of informal waste-workers in Tunisia, Morocco, and Palestine, where they perceived themselves as abandoned and rejected, and wished to change their occupation. This self-perception was different when they were active in higher stages of the waste value chain, such as semi-professional or professional recyclers. They tend to have access to better resources and equipment, making it possible to collect more waste and trade with recycling companies directly or the public sector. In this case, they appear to be content with their jobs and look on themselves as business men and service providers (Scheinberg and Savain, 2015).

\subsection{Current policies and waste governance regarding the informal sector}

The perception of the informal sector's activities can vary depending on the country (Nas and Jaffe, 2004). The informal sector are perceived as negative, this being reflected in national policies and the relevant legal context. Medina (2000) and Wilson et al. (2006) mention repression, neglect and collusion in public policies, including aggressive measures to suppress these activities and sometimes exploitation by local authorities. Scheinberg and Savain (2015) cited the examples of Algeria and Jordan, where informal recyclers are arrested or fined.

As a result, informal waste-workers are seen as suspect, and the relationship between the formal and informal sector is frequently defined by mistrust and competition (Scheinberg and Savain, 2015). The authorities and the police are openly hostile towards them, as well as being subject to bribery to be given access to the waste (Ezeah et al., 2013; Katusiimeh et al., 2013; Baud et al., 2001). In Uganda, private waste companies rarely cooperate with the informal sector due to its perceived illegality. On the other hand, informal waste-workers are reported as having to pay bribes to the local authorities in order to avoid being arrested for dumping in illegal sites, and they also accuse the formal sector of having taken advantage of their situation be paying at lower rates. Further conflicts are related to geographical competition and access to waste resources (Katusiimeh et al., 2013; Scheinberg and Savain, 2015). Furthermore, Baud et al. (2001) report that the local authorities in Chennai (India), Manila (the Philippines) and Lima (Peru) prefer to cooperate with NGOs and large waste management enterprises rather that trade with the informal sector. They are only prepared to engage with the latter after its formalization, e.g. through NGOs or community-based organization (CBO) mediation.

\subsection{Experiences with formalization}

Despite the conflicts and rejection policies, low-and middleincome countries have started to recognize the need to resolve environmental, social and economic issues related to their MSWM systems, changing their previous attitude of opposition and indifference into one of active support or "stimulation" (Medina, 2000; Wilson et al., 2006; Kashyap and Visvanathan, 2014). Governments are acknowledging the positive contribution of the informal sector, and have begun considering its inclusion in formal waste management systems (Nas and Jaffe, 2004; Marello and Helwege, 2014). This change can be observed in recent waste policies and legal frameworks of countries such as Brazil, where the National Solid Waste Policy recognizes informal recyclers as important stakeholders of the MSWM system, pointing out the need to include recycling associations and cooperatives in separate collection and recycling programs, and making their inclusion in the reverse logistic mandatory (Gutberlet, 2011; Dias, 2010).
Likewise, the Colombian waste policy framework includes a $3 \mathrm{R}$ waste hierarchy and enables the participation of marginalized or discriminated groups in bidding processes (Terraza and Sturzenegger, 2010). In Peru, Law N 29419 supports the formalization of informal recyclers and requires local governments to support the creation of associations, cooperatives and MSEs and to include them in separate public collection and recycling programs. In Kingston, Jamaica, informal recyclers working in CBO activities are stimulated through their inclusion in the National Solid Waste Management Reorganization Scheme, which aims to improve their economic and health security (Nas and Jaffe, 2004).

Similar changes are taking place in India, the Philippines and Bangladesh too. In India, national policies such as the National Action Plan for Climate Change of 2009 and the National Environment Policy of 2006 recognize the informal waste sector as the core of the recycling system, thus highlighting the need for formalization, actively supporting the creation of cooperatives and involving organized recyclers in door-to-door collection. The National Framework for the Informal Sector in Solid Waste Management in the Philippines aims to integrate the informal sector by providing it with a favorable policy environment, skills development, and access to secure livelihoods, employment and social services. Further, in Bangladesh, the National 3R Strategy supports the participation of the informal sector in recycling (Kashyap and Visvanathan, 2014).

Unlike the examples mentioned above, countries such as Indonesia, Jordan, Yemen, Algeria, Egypt and Lebanon are in a different stage of development regarding their recycling goals and formalization strategies. While the role of waste management is recognized by these countries as a driver of climate change and related social issues, they still lack policy instruments for including the informal sector in their waste management systems (Scheinberg and Savain, 2015; GIZ, no date). Morocco is the only country in the Africa and Middle East region with a national policy that recognizes the informal sector as part of the private sector and authorizes it to collect recyclables (Scheinberg and Savain, 2015; PNDM, 2007).

Policies and legal changes allowing the formalization of the informal sector are key aspect. However, as an important stakeholder of waste management systems, the informal sector also plays an important role the success or failure of formalization initiatives. The literature regarding the willingness and interest of informal recyclers to be formalized is not extensive, but some studies indicate the unwillingness and reluctance of informal recyclers to be formalized, due to their perception that they would lose their work flexibility and autonomy (ESCAP, 2015; Burcea, 2015; Coffey and Coad, 2010). Other formalization experiences in low-and middleincome countries have shown the readiness of informal wasteworkers to be formalized as long as this happens in a participatory way and based on a stakeholder consultation process that includes them, fulfilling their expectations and needs regarding working conditions, income, flexibility and empowerment, among other issues (Gutberlet, 2011, 2012; Terraza and Sturzenegger, 2010; Gunsilius et al. 2011b; ESCAP, 2015; Scheinberg and Savain, 2015).

\subsection{Current approaches to formalization}

\subsubsection{Based on organizing informal waste-workers in associations and cooperatives}

In this model, municipalities and formalized waste-workers organized in associations or cooperatives establish contracts or cooperation agreements for performing collection services and recycling. Examples of this model can be found in the Philippines, Brazil, Colombia and Peru, among other countries, where informal waste-workers have been organized through the initiative of NGOs and municipalities (Wilson et al., 2009; Velis et al., 2012; 
Gutberlet, 2012; Gunsilius et al., 2011a; Abarca et al., 2013; Aparcana and Salhofer, 2013; Terraza and Sturzenegger, 2010). Mostly, their income is not fixed but depends strongly on the quantity and quality of collected recyclable materials, which are sold in the local recycling market. However, in other cases, the economic sustainability of the model has been ensured through changes in waste policies and regulations. In Diadema and Londrina (Brazil), the incomes are the result of a combined approach: partially based on the sale of recyclable materials, the amount of waste not diverted to the landfill, and fixed waste fees paid by the municipality based on the area covered by the collection service (Yates and Gutberlet, 2011).

In addition to their role as initiators, NGOs may provide technical, financial and social assistance to associations in the form of social aid projects aiming to help informal waste-workers and alleviate their poverty. Some authors have criticized this aspect due to the focus on social problems, instead of recognizing the economic, social and political contributions of the informal sector (Scheinberg et al., 2006). Gutberlet (2012) proposes an alternative to this in the form of a 'Participatory Sustainable Waste Management' (PSWM) approach, which has been successfully implemented in some formalization processes related to associations and cooperatives in Diadema and São Paulo (Brazil). This approach aims at the implementation of 'solid waste recovery, reuse and recycling practices with organized and empowered recycling cooperatives supported with public policies, embedded in solidarity economy, targeting social equity and environmental sustainability'. PSWM is based on the achievement of collective goals in the direction of common economic development (the solidarity economy), the formulation of democratic waste management policies and participatory management (Gutberlet, 2012).

\subsubsection{Based on organizing recyclers in $\mathrm{CBO}$ (Community Based Organizations) or MSEs (Micro- and Small Enterprises)}

CBOs are formed when individuals organize themselves to provide waste services in their communities. Here, people living in poor neighborhoods are often confronted with bad living conditions, high unemployment, low legal and social status, and a lack of basic sanitary services in the community, such as waste management. For poor community members (informal waste-workers, the elderly, the disabled and the unemployed), this situation often represents both an opportunity to exploit a possible source of income from providing waste services and recycling materials, and the need to create a clean environment for themselves and their community (WASTE, 2001).

In this approach the municipality plays a minor role, providing support through supplying regulations, equipment and infrastructure, awareness- raising activities, etc. The incomes of formalized waste-workers are mostly covered by waste collection fees (paid by users) and, in cases of recycling, from selling the recycled materials (SANDEC, 1996). Depending on need and the recycling market, CBOs can perform waste collection, sorting and recycling, composting and the cleaning of public areas, among others activities.

Informal waste-workers may also formalize their activities by forming themselves into micro- and small enterprises (MSEs) to provide waste services to their communities (waste collection, street sweeping, recycling). SANDEC (1996) describes this model as involving ordinary citizens as beneficiaries, with the local government or municipalities being the legally responsible entity contracting the MSEs. In the model described by SANDEC (1996), incomes are generated by waste fees collected by the municipality, which are paid on to the MSEs. NGOs play the roles of consultancies and technical assistance providers, especially during the implementation phase of the model. Further, in some cases, they might provide financial assistance in the form of starting capital together with local banks.
Baud et al. (2001) analyzed the functioning of the MSE model in metropolitan Lima, Peru, where pilot projects showed the technical feasibility of implementing this system for collecting and recycling waste, especially in poorly served and inaccessible areas. The model was initiated by the NGO IPES, which provided technical and financial assistance to start 140 MSEs, mainly run by women from poor communities. In this case, residents supervised the quality of the services and paid the local government, which in turn paid the MSEs. However, the authors point out the unsustainability of this model due to the irregularity of payments from the local authorities to the MSEs, leading to the latter collapsing. The same study described more successful results for a second MSE model, which envisaged closer interaction with the users (local communities). In addition to supervising the quality of the services, the community paid for the services direct to the MSEs, thus ensuring a continuous flow of income and permitting the MSEs to survive (Baud et al., 2001).

\subsubsection{Based on adopting informal waste-workers as workers for the formal waste management sector}

Informal waste activities may be also formalized through collaboration in performing certain activities, as they have the necessary capacities for it (experience, equipment, lower costs). Schmied et al. (2011) mention the "TransWaste" project, where formalization was proposed based on cooperation between the Austrian public waste sector, the private sector (represented by waste management social enterprises or re-use enterprises in Austria or Hungary), and informal Hungarian collectors. Gunsilius et al. (2011a) present the example of Wongpanit Co. Ltd in Thailand, which buys recyclable materials from households, waste pickers, collection crews, smaller junk shops, etc. and provides them with diverse social services and support programs, such as training in occupational health and safety among other things. The company also offers training for poor and disadvantaged people, employing some of them at the recycling facility (Sang-Arun et al., 2014).

The public and private formal sectors may also recruit informal waste-workers as formal workers performing waste collection or at recycling facilities. This approach can be classified as 'traditional', with informal recyclers typically being seen as 'poor people' with social problems, the aim being to 'help' them and 'alleviate their poverty'. This tends to ignore the importance of informal recyclers in the waste management system and tries to improve their situation, without addressing the social and political factors that influence it (Scheinberg et al., 2006).

For example, Gunsilius et al. (2011a) mention the case of the extraction of alternative fuels and raw materials (AFR) from waste for cement production in Iloilo City (the Philippines). The project began by employing thirty waste pickers at the recycling plant, later increasing to sixty. In Indonesia, the recycling enterprise Banda Ache Plastic Recycling not only cooperates with junk collectors, itinerant buyers and waste pickers, which are registered members of a waste recycling association, but also employs seventeen former waste pickers at the recycling plant. Some social benefits included in this approach are free elementary schools, job security, holiday entitlements, and regular and steady salary (Kashyap and Visvanathan, 2014). In 2002, the city of Surabaya (Indonesia) implemented a new MSWM system based, where households separate their waste into "dry" and "wet" materials. The "dry" materials are collected by neighbourhood associations, who hire waste-collectors (former waste-pickers), provide pushcarts, and pay salaries to them for their services in collecting and transporting waste from household units to transfer stations (Premakumara, 2012). Further examples of this approach can be found in India (Rathi, 2006; Baud et al., 2001), Peru (Aparcana and Salhofer, 2013), Indonesia (Zurbrügg et al., 2012) and Argentina (Parizeau, 2011), among others. 


\subsection{Barriers and enabling factors regarding sustainable formalization}

Several studies have analyzed the factors or barriers that prevent MSWM systems in low-and middle-income countries from becoming sustainable. Abarca et al. (2013) grouped these barriers into the following categories: technical, environmental, financial/ economic, socio-cultural, institutional/organizational and politi$\mathrm{cal} /$ legal. Further research confirms this categorization and describes similar problems within each category (Ezeah and Roberts, 2012; Abarca et al., 2013; Troschinetz and Mihelcic, 2009; UN-HABITAT, 2010; Cointreau-Levine, 1994; Ogawa, 1996; Wang and Geng, 2012).

Research into the barriers affecting formalization has moved towards proposing different approaches to assessing formalization initiatives, aiming at identifying not only the typical barriers, but also the enabling factors that lead formalization initiatives to be successful and sustainable in the long term. For instance, Zurbrügg et al. (2012) propose three assessment criteria for formalization initiatives: (i) social mobilization and acceptance (social element); (ii) stakeholder, legal and institutional arrangements comprising roles, responsibilities and management functions (policy and institutional element); and (iii) financial and operational requirements, as well as cost-recovery mechanisms (economic element). Furthermore, Velis et al. (2012) developed an assessment tool called 'InterRa', which is based on a typology for classifying possible interventions to promote the integration of informal recycling systems in a city's SWM system. The authors consider three primary intervention categories (the SWM system, the materials and value chain, and society as a whole) underpinned by the organizational and empowerment dimensions. The authors suggest that a balanced development of all four intervention categories would increase the chances of successful formalization. Moreover, they conclude that the organization and empowerment of informal waste-recyclers is a key factor enabling MSWM systems to change in the direction of more fully integrated systems (Velis et al., 2012).

Velis et al. (2012), Zurbrügg et al. (2012), Abarca et al. (2013) and some other authors show interesting similarities regarding their assessment criteria and their views of the factors that characterize successfully implemented formalization initiatives. These studies point out the importance of including policy, institutional, social and financial measures in maximizing the chances of a formalization process being successful.

Building on this, the present paper sorts interventions regarding formalization into five categories: (1) policy and legal arrangements; (2) economic/financial instruments; (3) institutional and organizational arrangements; (4) actions regarding welfare and social acceptance; and (5) technical/operational interventions. Table 1 presents some of the typical issues identified in each category, including common actions leading to successful formalization, regardless of approach.

\subsection{Review of case studies}

Table 2 presents a review of twenty case studies of formalization experiences, carried out with the aim of identifying first, the type of formalization approach implemented and its main characteristics according to the case study; and secondly, the presence

Table 1

Classification of common barriers to formalization and enabling measures for their removal.

\begin{tabular}{|c|c|}
\hline Categories & Barriers to formalization (various authors) \\
\hline $\begin{array}{l}\text { Policy and legal } \\
\text { arrangements }\end{array}$ & $\begin{array}{l}\text { - Absence of adequate policies, clear legislation and strong regula- } \\
\text { tions (Abarca et al., 2013) } \\
\text { - Waste legislation is fragmented into different laws, causing the } \\
\text { lack of many important elements (technologies, cost-effective } \\
\text { aspects, enforcement mechanisms) (Abarca et al., 2013; } \\
\text { Troschinetz and Mihelcic, 2009; Ezeah and Roberts, 2012) }\end{array}$ \\
\hline $\begin{array}{l}\text { Economic/financial } \\
\text { instruments }\end{array}$ & $\begin{array}{l}\text { - Budgetary constraints, lack of economic support from the central } \\
\text { government, weak strategies for raising funds from residents, } \\
\text { inappropriate economic and financial planning (Ezeah and } \\
\text { Roberts, 2012; Abarca et al., 2013; Troschinetz and Mihelcic, } \\
\text { 2009; UN-HABITAT, 2010; Cointreau-Levine, 1994; Ogawa, 1996) }\end{array}$ \\
\hline $\begin{array}{l}\text { Institutional/ } \\
\text { organizational } \\
\text { arrangements }\end{array}$ & $\begin{array}{l}\text { - Lack of organizational capacities and managerial skills (leader- } \\
\text { ship) of local authorities (Abarca et al., 2013; Wang and Geng, } \\
\text { 2012; Troschinetz and Mihelcic, 2009) } \\
\text { - Perception that environment protection conflicts with national } \\
\text { economic goals (Wang and Geng, 2012) } \\
\text { - Sharing of similar roles and responsibilities, confusion regarding } \\
\text { their delineation and distribution. Cross-agency collaboration rare } \\
\text { (Wang and Geng, 2012) }\end{array}$ \\
\hline $\begin{array}{l}\text { Social acceptance and } \\
\text { welfare }\end{array}$ & $\begin{array}{l}\text { - Lack of educational and awareness campaigns regarding the } \\
\text { importance of a proper waste management system and the role } \\
\text { of citizens as waste generators (Abarca et al., 2013; Wang and } \\
\text { Geng, 2012) } \\
\text { - Social rejection: working as a recycler is associated with low sta- } \\
\text { tus and considered undesirable. There is a general disrespect for } \\
\text { the work, producing low working ethics of workers and poor qual- } \\
\text { ity of their work (Ogawa, 1996; Abarca et al., 2013) }\end{array}$ \\
\hline
\end{tabular}

Technical/operational - Unavailability of technology and/or human work force, lack of skilled personnel with technical expertise on waste management, lack of country appropriated technology, deficient waste equipment and structures (waste transfer stations, storages, old waste vehicles, etc.), poor roads, unreliable data and lack of information-sharing between stakeholders (Troschinetz and Mihelcic, 2009; Abarca et al., 2013; Wang and Geng, 2012; Ezeah and Roberts, 2012)
Common recommended measures/interventions towards formalization (Adapted from Velis et al. 2012)

\author{
- Favorable national policies, regulations, political support nation- \\ ally and locally, law enforcement
}

- Eco-efficiency: reductions in packaging, producer responsibility

- Microcredit initiatives, expansion of capital basis, financial incentives

- Entering of new service roles and niches (diversification of services); increase in bargaining power

- Appropriate payment schemes reducing economic uncertainty

- Organization of the informal sector, formation of cooperatives $/ \mathrm{mi}$ cro- and small enterprises, cooperatives and associations

- Stakeholder involvement, collaboration and partnerships among stakeholders of waste management systems, good relationship with the receiving industries and the formal MSWM system, national initiative-participatory approach

- Information and education campaigns, training and empowerment of the various stakeholders

- Acknowledgment

- and acceptance by authorities of benefits that informal recycling can provide, inclusion of informal recycling into waste management, political and legal recognition, acceptance by the public, change to policy makers' perceptions about informal recycling activities

- Occupational safety practices, social and environmental health, improvement of working conditions and equipment

- Assessing and documenting existing MSWM system, accurate data collection regarding waste and recycling markets, data quality

Pilot projects

- Technical/operational requirements: access to adequate sorting and storage spaces, infrastructure, topographical considerations, improved quality of secondary raw materials

- Appropriate technology, economic and technical assistance, technical capacity-building for waste workers 
Table 2

\begin{tabular}{|c|c|c|c|c|c|c|c|c|c|c|c|c|c|}
\hline \multirow{2}{*}{$\begin{array}{l}\text { Formalization } \\
\text { approaches }\end{array}$} & \multirow[t]{2}{*}{ Case study } & \multicolumn{5}{|c|}{ Presence of interventions } & \multicolumn{4}{|c|}{ Further characteristics } & \multicolumn{2}{|c|}{ Barriers and success factors } & \multirow[t]{2}{*}{ Reference } \\
\hline & & Policy & $\begin{array}{l}\text { Economic/financial } \\
\text { instruments }\end{array}$ & $\begin{array}{l}\text { Institutional/ } \\
\text { organizational }\end{array}$ & Social & Technical & Initiator & $\begin{array}{l}\text { Externally } \\
\text { financed }\end{array}$ & $\begin{array}{l}\text { Hiring } \\
\text { scheme }\end{array}$ & Income & $\begin{array}{l}\text { Success factors/ } \\
\text { enabling measures }\end{array}$ & $\begin{array}{l}\text { Persistent } \\
\text { barriers/ } \\
\text { challenges }\end{array}$ & \\
\hline \multirow[t]{4}{*}{$\begin{array}{l}\text { Recyclers' } \\
\text { associations and/ } \\
\text { or cooperatives }\end{array}$} & $\begin{array}{l}\text { Linis Ganda } \\
\text { Programme, } \\
\text { Metro } \\
\text { Manila } \\
\text { (Philippines) }\end{array}$ & Yes & Yes & Yes & Yes & Yes & $\begin{array}{l}\text { NGOs, } \\
\text { Municipality }\end{array}$ & $\begin{array}{l}\text { Not } \\
\text { mentioned }\end{array}$ & $\begin{array}{l}\text { Association } \\
\text { members }\end{array}$ & $\begin{array}{l}\text { Variable } \\
\text { (based on the } \\
\text { amounts of } \\
\text { sold recyclable } \\
\text { material) }\end{array}$ & $\begin{array}{l}\text { Diversification of } \\
\text { products (eg. } \\
\text { recycled purses; } \\
\text { Alternative } \\
\text { Refused Fuel in } \\
\text { pellets instead } \\
\text { charcoal); strong } \\
\text { leadership of } \\
\text { recyclers; support } \\
\text { of public } \\
\text { authorities }\end{array}$ & $\begin{array}{l}\text { Corruption or } \\
\text { illegal activities } \\
\text { around waste } \\
\text { services; power } \\
\text { conflicts between } \\
\text { some authorities } \\
\text { and associations }\end{array}$ & $\begin{array}{l}\text { UN-HABITAT } \\
\text { (1998) - Ciu- } \\
\text { dades para un } \\
\text { Futuro mas } \\
\text { sostenible; } \\
\text { Bennagen } \\
\text { et al. (2002) }\end{array}$ \\
\hline & $\begin{array}{l}\text { Iloilo City } \\
\text { (The } \\
\text { Philippines) }\end{array}$ & Yes & $\begin{array}{l}\text { Yes (establishment } \\
\text { of a capital-built- } \\
\text { up through the } \\
\text { associations' } \\
\text { savings } \\
\text { programme) }\end{array}$ & Yes & Yes & Yes & Municipality & Yes & $\begin{array}{l}\text { Association } \\
\text { members }\end{array}$ & $\begin{array}{l}\text { Mixed } \\
\text { (depending on } \\
\text { the type of } \\
\text { activity done } \\
\text { by the } \\
\text { association: } \\
\text { based on the } \\
\text { amounts of } \\
\text { sold materials } \\
\text { and some fixed } \\
\text { incomes, e.g. } \\
\text { security } \\
\text { services, } \\
\text { support } \\
\text { personnel for } \\
\text { landfill) }\end{array}$ & $\begin{array}{l}\text { Development of } \\
\text { capacities for } \\
\text { providing local } \\
\text { services and } \\
\text { products; pilot } \\
\text { projects for } \\
\text { developing and } \\
\text { testing new } \\
\text { options for } \\
\text { material } \\
\text { recovering; } \\
\text { diversification of } \\
\text { products and } \\
\text { services; active } \\
\text { stakeholders } \\
\text { involvement to } \\
\text { identify demand of } \\
\text { the local market }\end{array}$ & $\begin{array}{l}\text { Further capacity } \\
\text { building; technical } \\
\text { support and } \\
\text { awareness; need } \\
\text { for exploring other } \\
\text { materials for } \\
\text { handicraft } \\
\text { recycling } \\
\text { (according the } \\
\text { market } \\
\text { development); } \\
\text { lack of data } \\
\text { regarding waste } \\
\text { composition, } \\
\text { quality, material } \\
\text { prices, current } \\
\text { situation of } \\
\text { informal waste } \\
\text { pickers }\end{array}$ & $\begin{array}{l}\text { Paul et al. } \\
\text { (2012) }\end{array}$ \\
\hline & $\begin{array}{l}\text { Joao Pessoa } \\
\text { (Brasil) }\end{array}$ & Yes & Not mentioned & Yes & Yes & Yes & Municipality & Yes & $\begin{array}{l}\text { Association } \\
\text { members }\end{array}$ & $\begin{array}{l}\text { Variable } \\
\text { (based on the } \\
\text { amounts of } \\
\text { sold recyclable } \\
\text { material) }\end{array}$ & $\begin{array}{l}\text { Commitment of } \\
\text { local government } \\
\text { through } \\
\text { investment and } \\
\text { coordination; } \\
\text { capacity building; } \\
\text { awareness raise } \\
\text { activities among } \\
\text { citizens and } \\
\text { recyclers; } \\
\text { education } \\
\text { programs for } \\
\text { adults }\end{array}$ & $\begin{array}{l}\text { Lack of awareness } \\
\text { of the community; } \\
\text { lack of } \\
\text { management } \\
\text { capacities in the } \\
\text { public } \\
\text { admministration; } \\
\text { low educational } \\
\text { level and lack of } \\
\text { information and } \\
\text { trust of informal } \\
\text { recylers }\end{array}$ & $\begin{array}{l}\text { UN-HABITAT } \\
\text { - Ciudades } \\
\text { para un } \\
\text { Futuro mas } \\
\text { sostenible } \\
(2004)\end{array}$ \\
\hline & $\begin{array}{l}\text { Medellin } \\
\text { (Colombia) }\end{array}$ & Yes & Yes & Yes & Yes & Yes & Recyclers & $\begin{array}{l}\text { Not } \\
\text { mentioned }\end{array}$ & $\begin{array}{l}\text { Association } \\
\text { members }\end{array}$ & Fixed & $\begin{array}{l}\text { Diversification of } \\
\text { services (in } \\
\text { addition to } \\
\text { collection and } \\
\text { recycling: cleaning } \\
\text { services, por } \\
\text { public and private } \\
\text { institutions) }\end{array}$ & Not mentioned & $\begin{array}{l}\text { Web site: } \\
\text { RECUPERAR; } \\
\text { Medina } \\
\text { (2000) }\end{array}$ \\
\hline
\end{tabular}

(continued on next page) 


Institutional/

Social
Technical Initiator

Externally Hiring

Income

Success facto

Persistent barriers/

\begin{tabular}{|c|c|c|c|c|c|c|c|c|c|c|c|c|}
\hline $\begin{array}{l}\text { Bogota } \\
\text { (Colombia) }\end{array}$ & Yes & Yes & Yes & Yes & Yes & Recyclers & Yes & $\begin{array}{l}\text { Association } \\
\text { members }\end{array}$ & $\begin{array}{l}\text { Fixed (for } \\
\text { recyclers at } \\
\text { the recycling } \\
\text { plant) }\end{array}$ & $\begin{array}{l}\text { Diversification of } \\
\text { services (street } \\
\text { sweeping, capacity } \\
\text { building, and } \\
\text { awareness raising } \\
\text { services) }\end{array}$ & $\begin{array}{l}\text { High percentage of } \\
\text { rejected material }\end{array}$ & $\begin{array}{l}\text { Terraza and } \\
\text { Sturzenegger } \\
\text { (2010), } \\
\text { WIEGO } \\
\text { (2009) }\end{array}$ \\
\hline $\begin{array}{l}\text { San Vicente } \\
\text { de Cañete } \\
\text { (Peru) }\end{array}$ & Yes & No & Yes & Yes & Yes & NGO & No & $\begin{array}{l}\text { Association } \\
\text { members }\end{array}$ & $\begin{array}{l}\text { Variable } \\
\text { (based on the } \\
\text { amounts of } \\
\text { sold recyclable } \\
\text { material) }\end{array}$ & $\begin{array}{l}\text { Awareness and } \\
\text { support from the } \\
\text { population; } \\
\text { increase of social } \\
\text { inclusion }\end{array}$ & $\begin{array}{l}\text { No diversification } \\
\text { of products or } \\
\text { services; lack of } \\
\text { finance } \\
\text { instruments for } \\
\text { recyclers; lack of } \\
\text { involvement and } \\
\text { awareness of the } \\
\text { municipality; } \\
\text { conflicts and } \\
\text { mistrust among } \\
\text { recyclers; income } \\
\text { depends on selling } \\
\text { prices }\end{array}$ & $\begin{array}{l}\text { Aparcana and } \\
\text { Salhofer } \\
\text { (2013) }\end{array}$ \\
\hline $\begin{array}{l}\text { Diadema } \\
\text { (Brazil) }\end{array}$ & Yes & $\begin{array}{l}\text { Yes (incentive in } \\
\text { the national solid } \\
\text { waste legislation) }\end{array}$ & Yes & Yes & Yes & Municipality & No & $\begin{array}{l}\text { Association } \\
\text { members }\end{array}$ & $\begin{array}{l}\text { Mixed } \\
\text { (revenues } \\
\text { from selling } \\
\text { materials and } \\
\text { also a fixed } \\
\text { payment for } \\
\text { the collection } \\
\text { services) }\end{array}$ & $\begin{array}{l}\text { Waste fees } \\
\text { partially based on } \\
\text { area served; } \\
\text { income does not } \\
\text { depend on the } \\
\text { market, } \\
\text { representing an } \\
\text { stable source of } \\
\text { income for } \\
\text { recyclers; strong } \\
\text { legal support from } \\
\text { the municipality; } \\
\text { diversification } \\
\text { (recycling and } \\
\text { collection) }\end{array}$ & Not mentioned & $\begin{array}{l}\text { Gutberlet } \\
\text { (2011); Yates } \\
\text { and Gutberlet } \\
\text { (2011) }\end{array}$ \\
\hline Pune (India) & Yes & Yes & Yes & Yes & Yes & Recyclers & No & $\begin{array}{l}\text { Association } \\
\text { members }\end{array}$ & $\begin{array}{l}\text { Mixed: from } \\
\text { user fees and } \\
\text { the sale of } \\
\text { recyclable } \\
\text { materials }\end{array}$ & $\begin{array}{l}\text { Diversification of } \\
\text { services and } \\
\text { products made of } \\
\text { recycled } \\
\text { materials; sorting } \\
\text { and storage places } \\
\text { for increasing } \\
\text { volume to be sold, } \\
\text { increasing } \\
\text { bargaining power }\end{array}$ & $\begin{array}{l}\text { Still low willigness } \\
\text { to pay (citizens); } \\
\text { health insurance } \\
\text { and pension } \\
\text { schemes Not } \\
\text { implemented. It is } \\
\text { expected to be } \\
\text { paid by the } \\
\text { municipality }\end{array}$ & $\begin{array}{l}\text { Chikarmane } \\
\text { (2012) }\end{array}$ \\
\hline $\begin{array}{l}\text { Mumbai } \\
\text { (India) }\end{array}$ & Yes & No & Yes & Yes & Yes & NGO & Yes & $\begin{array}{l}\text { Association } \\
\text { members }\end{array}$ & Fixed & $\begin{array}{l}\text { Descentralization } \\
\text { of waste service } \\
\text { delivery (for } \\
\text { increasing } \\
\text { coverage rate); } \\
\text { user pay principle; } \\
\text { minicipality plays } \\
\text { the role of } \\
\text { monitoring } \\
\text { instead of } \\
\text { delivering waste }\end{array}$ & $\begin{array}{l}\text { CBOs and NGOs } \\
\text { face the problem } \\
\text { of non- } \\
\text { participation from } \\
\text { some people in the } \\
\text { community; } \\
\text { problem with the } \\
\text { revenue recovery } \\
\text { from compost }\end{array}$ & $\begin{array}{l}\text { Rathi (2006), } \\
\text { Mahadevia } \\
\text { et al. (2005) }\end{array}$ \\
\hline
\end{tabular}




\begin{tabular}{|c|c|c|c|c|c|c|c|c|c|c|c|c|c|}
\hline \multirow{2}{*}{$\begin{array}{l}\text { Formalization } \\
\text { approaches }\end{array}$} & \multirow[t]{2}{*}{ Case study } & \multicolumn{5}{|c|}{ Presence of interventions } & \multicolumn{4}{|c|}{ Further characteristics } & \multicolumn{2}{|c|}{ Barriers and success factors } & \multirow[t]{2}{*}{ Reference } \\
\hline & & Policy & $\begin{array}{l}\text { Economic/financial } \\
\text { instruments }\end{array}$ & $\begin{array}{l}\text { Institutional/ } \\
\text { organizational }\end{array}$ & Social & Technical I & Initiator & $\begin{array}{l}\text { Externally } \\
\text { financed }\end{array}$ & $\begin{array}{l}\text { Hiring } \\
\text { scheme }\end{array}$ & Income & $\begin{array}{l}\text { Success factors/ } \\
\text { enabling measures }\end{array}$ & $\begin{array}{l}\text { Persistent } \\
\text { barriers/ } \\
\text { challenges }\end{array}$ & \\
\hline & $\begin{array}{l}\text { Londrina } \\
\text { (Brazil) }\end{array}$ & Yes & $\begin{array}{l}\text { Yes (incentive in } \\
\text { the national solid } \\
\text { waste legislation) }\end{array}$ & Yes & Yes & Yes & Municipality & No & $\begin{array}{l}\text { As } \\
\text { association } \\
\text { members }\end{array}$ & $\begin{array}{l}\text { Mixed (the } \\
\text { recyclers get } \\
\text { revenues from } \\
\text { selling } \\
\text { materials and } \\
\text { also a fixed } \\
\text { payment for } \\
\text { the collection } \\
\text { services) }\end{array}$ & $\begin{array}{l}\text { services; adequate } \\
\text { policies allowing } \\
\text { development of } \\
\text { community based } \\
\text { business } \\
\text { Waste fees } \\
\text { partially based on } \\
\text { area served; fair } \\
\text { payment system } \\
\text { of the recyclers } \\
\text { performing } \\
\text { various tasks in } \\
\text { recycling; high } \\
\text { level of } \\
\text { commitment of } \\
\text { the local } \\
\text { government; } \\
\text { contractual } \\
\text { relationship } \\
\text { between } \\
\text { government and } \\
\text { recyclers; } \\
\text { transparency; and } \\
\text { stakeholder } \\
\text { involvement }\end{array}$ & $\begin{array}{l}\text { Bad infrastructure } \\
\text { in recycling } \\
\text { centres; logistic } \\
\text { problems in } \\
\text { integrating the } \\
\text { system with the } \\
\text { recycling industry; } \\
\text { shortcomings } \\
\text { regarding } \\
\text { occupational } \\
\text { health }\end{array}$ & $\begin{array}{l}\text { Gutberlet } \\
\text { (2011), } \\
\text { Terraza and } \\
\text { Sturzenegger } \\
\text { (2010) }\end{array}$ \\
\hline \multirow[t]{3}{*}{$\begin{array}{l}\text { Recyclers forming } \\
\text { CBOs or MSEs } \\
\text { (within low } \\
\text { income } \\
\text { communities) }\end{array}$} & $\begin{array}{l}\text { MSEs in East } \\
\text { Africa } \\
\text { (Kenya, } \\
\text { Zambia, } \\
\text { Tanzania, } \\
\text { and Uganda) }\end{array}$ & $\begin{array}{l}\text { Yes (for } \\
\text { participation } \\
\text { of the private } \\
\text { sector) }\end{array}$ & Not mentioned & Yes & Yes & Yes & ILO & Yes & $\begin{array}{l}\text { As worker } \\
\text { for the } \\
\text { MSEs }\end{array}$ & $\begin{array}{l}\text { Fixed (based } \\
\text { on waste fees } \\
\text { for collection } \\
\text { service and } \\
\text { contracts with } \\
\text { the } \\
\text { municipality) }\end{array}$ & Privatization & $\begin{array}{l}\text { Lack of business } \\
\text { capacities ansd } \\
\text { strategy; no } \\
\text { financial } \\
\text { sustainability, } \\
\text { depending on } \\
\text { external grants; } \\
\text { lack of support } \\
\text { from the local } \\
\text { authorities; poor } \\
\text { working } \\
\text { conditions; } \\
\text { unwillingness to } \\
\text { pay for the } \\
\text { collection service; } \\
\text { no possibility to } \\
\text { pay for low } \\
\text { income areas }\end{array}$ & $\begin{array}{l}\text { UN HABITAT } \\
\text { (2010); ILO } \\
\text { (2003) }\end{array}$ \\
\hline & $\begin{array}{l}\text { CBOs in } \\
\text { Nakuru } \\
\text { (Kenya) }\end{array}$ & $\begin{array}{l}\text { Yes (for } \\
\text { participation } \\
\text { of the private } \\
\text { sector) }\end{array}$ & Yes & Yes & Yes & Yes & $\begin{array}{l}\text { NGO, } \\
\text { municipality }\end{array}$ & Yes & $\begin{array}{l}\text { Recylers are } \\
\text { part of the } \\
\text { community } \\
\text { and } \\
\text { members of } \\
\text { the CBO }\end{array}$ & $\begin{array}{l}\text { Fixed } \\
\text { (regarding } \\
\text { waste fees for } \\
\text { collection and } \\
\text { transport) }\end{array}$ & $\begin{array}{l}\text { User pay principle } \\
\text { (for waste } \\
\text { services), } \\
\text { decentralization of } \\
\text { provision of waste } \\
\text { services, support } \\
\text { and involvement } \\
\text { of the public } \\
\text { sector }\end{array}$ & $\begin{array}{l}\text { Unwilligness to } \\
\text { pay of the citizens; } \\
\text { lack of awareness; } \\
\text { lack of financing of } \\
\text { investments; high } \\
\text { costs of licenses } \\
\text { for provision of } \\
\text { waste services; } \\
\text { lack of appropiate } \\
\text { disposal sites }\end{array}$ & $\begin{array}{l}\text { Mwanzia } \\
\text { et al. (2013) }\end{array}$ \\
\hline & $\begin{array}{l}\text { MSEs in } \\
\text { Comayagua }\end{array}$ & $\begin{array}{l}\text { Yes (for } \\
\text { participation }\end{array}$ & Not mentioned & Yes & Yes & Yes & NGO & Yes & $\begin{array}{l}\text { As worker } \\
\text { for the }\end{array}$ & $\begin{array}{l}\text { Variable } \\
\text { (depending on }\end{array}$ & $\begin{array}{l}\text { Cooperation and } \\
\text { agreements with }\end{array}$ & Not mentioned & $\begin{array}{l}\text { DANIDA - } \\
\text { PREMACA }\end{array}$ \\
\hline
\end{tabular}




\begin{tabular}{|c|c|c|c|c|c|c|c|c|c|c|c|c|c|}
\hline \multirow{2}{*}{$\begin{array}{l}\text { Formalization } \\
\text { approaches }\end{array}$} & \multirow[t]{2}{*}{ Case study } & \multicolumn{5}{|c|}{ Presence of interventions } & \multicolumn{4}{|c|}{ Further characteristics } & \multicolumn{2}{|c|}{ Barriers and success factors } & \multirow[t]{2}{*}{ Reference } \\
\hline & & Policy & $\begin{array}{l}\text { Economic/financial } \\
\text { instruments }\end{array}$ & $\begin{array}{l}\text { Institutional/ } \\
\text { organizational }\end{array}$ & Social & Technical & Initiator & $\begin{array}{l}\text { Externally } \\
\text { financed }\end{array}$ & $\begin{array}{l}\text { Hiring } \\
\text { scheme }\end{array}$ & Income & $\begin{array}{l}\text { Success factors/ } \\
\text { enabling measures }\end{array}$ & $\begin{array}{l}\text { Persistent } \\
\text { barriers/ } \\
\text { challenges }\end{array}$ & \\
\hline & (Honduras) & $\begin{array}{l}\text { of the private } \\
\text { sector) }\end{array}$ & & & & & & & MSEs & $\begin{array}{l}\text { sales of } \\
\text { recyclable } \\
\text { materials) }\end{array}$ & $\begin{array}{l}\text { waste generators, } \\
\text { such as residents, } \\
\text { private companies, } \\
\text { schools, hotels. } \\
\text { Raising awareness } \\
\text { and support from } \\
\text { the municipality }\end{array}$ & & (2012) \\
\hline & $\begin{array}{l}\text { CBOs in } \\
\text { Cairo (Egypt) }\end{array}$ & $\begin{array}{l}\text { Not } \\
\text { mentioned }\end{array}$ & No & Yes & Yes & Yes & NGO & No & $\begin{array}{l}\text { Recylers } \\
\text { (women) } \\
\text { are part of } \\
\text { the } \\
\text { community } \\
\text { and } \\
\text { members of } \\
\text { the CBO }\end{array}$ & Not mentioned & $\begin{array}{l}\text { Product } \\
\text { diversification: } \\
\text { paper recycling } \\
\text { and further paper } \\
\text { derived products } \\
\text { such as paper } \\
\text { bags, cards, etc. }\end{array}$ & $\begin{array}{l}\text { Protective } \\
\text { approach; lack of } \\
\text { empowerment of } \\
\text { recyclers }\end{array}$ & GIZ (2010) \\
\hline & $\begin{array}{l}\text { CBOs in } \\
\text { Mombasa } \\
\text { (Kenya) }\end{array}$ & $\begin{array}{l}\text { Still in } \\
\text { process (At } \\
\text { the time of } \\
\text { the report). } \\
\text { Some } \\
\text { support from } \\
\text { the } \\
\text { municipality }\end{array}$ & $\begin{array}{l}\text { Yes trust fund for } \\
\text { recyclers) }\end{array}$ & Yes & Yes & Yes & NGO & No & $\begin{array}{l}\text { Recylers are } \\
\text { part of the } \\
\text { community } \\
\text { and } \\
\text { members of } \\
\text { the CBO }\end{array}$ & Not mentioned & Improved services & $\begin{array}{l}\text { By-Laws allowing } \\
\text { recyclers to } \\
\text { provide waste } \\
\text { services are still in } \\
\text { process; lack of } \\
\text { support by the } \\
\text { Municipal Council } \\
\text { in waste transport } \\
\text { and providing } \\
\text { waste transfers } \\
\text { and sorting } \\
\text { stations; } \\
\text { corruption within } \\
\text { the network; lack } \\
\text { of commintment } \\
\text { of recyclers to stay } \\
\text { in ther } \\
\text { organizations; } \\
\text { weak leadership or } \\
\text { recyclers; lack of } \\
\text { technical } \\
\text { capacities; lack of } \\
\text { health schemes for } \\
\text { recyclers }\end{array}$ & $\begin{array}{l}\text { Kuria and } \\
\text { Muasya } \\
\text { (2010) }\end{array}$ \\
\hline \multirow[t]{2}{*}{$\begin{array}{l}\text { As formal workers } \\
\text { (for private } \\
\text { companies, } \\
\text { municipalities, } \\
\text { CBOs, or for MSEs) }\end{array}$} & $\begin{array}{l}\text { Gianyar } \\
\text { (Indonesia) }\end{array}$ & $\begin{array}{l}\text { Yes (based on } \\
\text { 3R hierarchy) }\end{array}$ & & $\begin{array}{l}\text { Yes (stakeholder } \\
\text { consultation at the local } \\
\text { level) }\end{array}$ & Yes & Yes & $\begin{array}{l}\text { Rotary Club } \\
\text { of Bali Ubud } \\
\text { and a local } \\
\text { NGO. }\end{array}$ & Yes & $\begin{array}{l}\text { As waste } \\
\text { workers at } \\
\text { the } \\
\text { composting } \\
\text { plant }\end{array}$ & Not mentioned & $\begin{array}{l}\text { Involvement of } \\
\text { local stakeholders, } \\
\text { reduced social } \\
\text { conflicts }\end{array}$ & $\begin{array}{l}\text { Difficulties in } \\
\text { selling the } \\
\text { compost to the } \\
\text { agriculture sector, } \\
\text { due to subsidized } \\
\text { chemical } \\
\text { fertilizers; lack of } \\
\text { a good marketing } \\
\text { strategy of the } \\
\text { compost (for cost } \\
\text { recovery) }\end{array}$ & $\begin{array}{l}\text { Zurbrügg } \\
\text { et al. (2012) }\end{array}$ \\
\hline & $\begin{array}{l}\text { Santiago de } \\
\text { Surco (Peru) }\end{array}$ & $\begin{array}{l}\text { Yes (not } \\
\text { specific for } \\
\text { supporting } \\
\text { this model) }\end{array}$ & No & No & Yes & Yes & Municipality & No & $\begin{array}{l}\text { As formal } \\
\text { waste } \\
\text { workers }\end{array}$ & Fixed & $\begin{array}{l}\text { Municipality } \\
\text { represents an } \\
\text { stable finance } \\
\text { source for the } \\
\text { system, covering } \\
\text { fixed and variable }\end{array}$ & $\begin{array}{l}\text { Only short termn } \\
\text { contracts with } \\
\text { formalized } \\
\text { recyclers; no full } \\
\text { access to health } \\
\text { services, therefore }\end{array}$ & $\begin{array}{l}\text { Aparcana and } \\
\text { Salhofer } \\
\text { (2013) }\end{array}$ \\
\hline
\end{tabular}


Income

Success factors/ Persisten enabling measures barriers/ challenges

Dhaka Yes (based on Yes (Bangladesh) 3R hierarchy)

Banda Ache Yes (based on No

Plastic

(Indonesia)

3R hierarchy)

\section{Chennai city Yes (not \\ specific for

this model
No

$\begin{array}{lll}\text { Yes } \quad \text { Yes } & \begin{array}{l}\text { NGO, } \\ \text { international } \\ \text { private sector }\end{array}\end{array}$

Yes (recyclers in

as individual workers

\begin{abstract}
Yes
\end{abstract}
Yes

company

Yes

and

costs. The system no full elimination

does Not depend of social problem

on the recycling low motivation

fluctuations

regarding their

job, low job

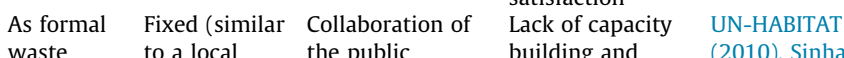

workers for municipal the public lathoriting and

waste waste worker) revenues based on stakeholders IWPAR (no

collection compost sales and regarding the date)

and at a CDM certificates, Clean

compost creation of Development

plant demand for Mechanism (CDM)

compost, national process:

policy supports difficulties to fulfil

use of compost for the compost

agriculture, strong regulation:

marketing difficulties in

partners, interest obtaining permits

of local banks, and licences

transparency and

good governance

good governance
through CDM

As formal Fixed (similar Social benefits Not mentioned Kashyap and

waste to a local including Visvanathan

workers municipal elementary

(2014)

sccurity; holiday

entitlements; and

regular and steady

salary without

with informal

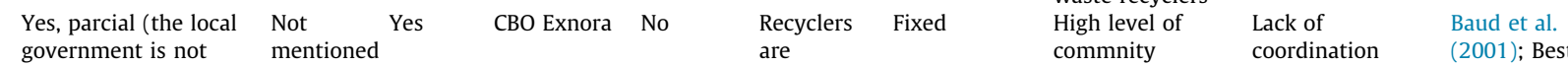

$\begin{array}{ll}\text { government is not mentioned } & \text { are } \\ \text { involved) } & \text { "adopted" }\end{array}$

nvolvement;

among

as

reduced wast

tariff for

Practices for

Human Set-

tlements: EX-

workers

NORA

effectiveness of

source separation

(UNESCO, no

financial viability

date)

and increase in

quality

employment for

the Street

Beautifiers 
and type of measure or intervention according to the five categories mentioned above (see Table 1). Beyond this, Table 2 presents some 'challenges' or 'persistent' barriers, which could not have been removed even after implementation of these measures; they thus remain as challenges to be overcome.

The review identifies measures to remove barriers in all five categories, regardless of the type of approach to formalization; however, it suggests a stronger link between the existence of measures in the policy/legal, institutional/organizational, and economic/financial categories and approaches 1 and 2. Without intending to establish any rule, this review shows that fixed salaries are preferred when applying formalization approach 3. Unlike this, approaches 1 and 2 tend to offer variable incomes or, in an effort to reduce economic uncertainty, a combination of variable and fixed salaries.

For the case studies in which informal waste-workers are organized as associations (approach 1 ) or as CBOs or MSEs (approach 2 ), policies and legal instruments support formalization specifically under these modalities, thus allowing recyclers to provide waste management services (e.g. collection and recycling). In these cases, the formalization was initiated through bottom-up actions started by local stakeholders (recyclers, NGOs, municipalities), which were scaled up in the case-study countries and incorporated into their national policies (Peru, Brazil, Colombia, Kenya, India). However, the existence of such policies does not ensure formalization. In addition, it is important to implement legal instruments to enforce these policies and to facilitate formalization process (Abarca et al., 2013; Velis et al., 2012; Gunsilius et al., 2011b).

In the case of the formalization approach based on contracting informal waste-workers as formal workers (approach 3), the initiatives emerged in countries with waste management policies promoting sustainable waste management practices, for instance, integrated waste management, 3R and other policies. Such strategies would drive the implementation of any measure enhancing the operational aspects of waste management, such as recycling rates, without necessarily being focused on how informal wasteworkers are incorporated into the waste management system. Therefore, it is important to enhance the focus of such policies, redirecting them towards the recognition of the contribution of informal sector and empowering them through MSWM policies and favorable regulations. As pointed out in the literature review (see Section 3.7), this aspect should be included as a basic component of any waste management strategy that is considering formalization, regardless of the approach applied.

The existence of institutional/organizational measures is also linked to the type of formalization. Organizing informal wasteworkers to form associations, CBOs or MSEs implies intensive participatory decision-making processes, with stakeholder engagement, partnerships, synergies and communication among stakeholders (e.g. municipalities, NGOs, formalized informal waste-workers) (Gunsilius et al., 2011a; Gutberlet, 2012; GIZ, 2010). The third formalization approach proposes contracting informal waste-workers as formal workers, frequently without close interaction with other stakeholders in the waste management system. Unlike the previous two formalization approaches, recyclers frequently do not participate in decision-making processes, nor do they cooperate with other relevant stakeholders.

This review also identifies the inclusion of financial and economic measures in formalization approaches 1 and 2 . The absence of finance instruments in the third approach may be explained by the type of employment arrangement between informal wasteworkers and the waste service provider as their employer. Measures along the technical and social dimensions are common in all three formalization models, regardless of the formalization approach. This is due to the fundamental goals, which usually include improving the socioeconomic situation of recyclers, as well as eliminating environmental problems related to waste management.

Regarding the kinds of persistent barriers, the most frequent were observed in the policy/legal, institutional/organizational, and economic/financial dimensions. $75 \%$ of the case studies reported problems in the policy/legal category. The most relevant barrier in this category appears to be the lack of empowerment of formalized waste-workers. Mostly, cities consider them to be a socially vulnerable group, instead of engaging them as important stakeholders, who contribute positively to the environment and local economy (Medina, 2000; Wilson et al., 2006; Scheinberg et al., 2006). The fact that a country or city has policies or strategies supporting formalization does not guarantee that formalized waste-workers are considered suitable providers of waste management services or valorization activities. This may cause formalization initiatives stumbling or even failing in the medium or long term due to a lack of political support on the part of national and local authorities, as in the cases of San Vicente de Caniete, Peru; MSEs in East Africa; Cairo, Egypt; Mombasa and Nakuru, Kenya; and Comayagua, Honduras). Policies that treat formalized wasteworkers as poor victims and disadvantaged may affect their status as important stakeholders, thus reducing their empowerment and bargaining power, and leading to them not being seen as waste management professionals (Scheinberg et al., 2006). This may lead municipalities to support private-sector initiatives (Gianyar, Indonesia; Dhaka, Bangladesh; Banda, Indonesia). The cases of Colombia (Medellin and Bogotá) and Brazil (Londrina, Diadema, João Pessoa) represent good examples of how governments have incorporated formalized waste-workers as a key relevant component of their waste management policies and strategies.

$50 \%$ of the case studies were affected by institutional or organizational issues after formalization. The most persistent barriers at this level are related to conflicts between public authorities and associations (metropolitan Manila, the Philippines), mistrust among waste-workers (San Vicente de Cañete, Peru, João Pessoa, Brazil), and corruption and illegal activities surrounding waste services (metropolitan Manila, Philippines, Mombasa, Kenya). Conflicts of interest and competition among stakeholders in the formal and informal sectors respectively, a lack of trust and corruption are problematic issues pointed out in the literature review, ones that are relevant even before formalization approaches are implemented (Medina, 2000; Wilson et al., 2006; Scheinberg and Savain, 2015; Ezeah et al., 2013; Katusiimeh et al., 2013; Baud et al., 2001).

Possible drivers for these problems after formalization may include the lack of transparency in institutional and organizational formalization processes, a lack of clarity in the policy and legal framework regarding formalization and in the distribution of roles and responsibilities between the formal sector and formalized waste-workers, and the lack of information and poor coordination among stakeholders (Wang and Geng, 2012). Also, weak leadership on the part of the formalized waste-workers and a lack of management capacities in the public administration may be the source of the most persistent institutional barriers (Abarca et al., 2013; Wang and Geng, 2012; Troschinetz and Mihelcic, 2009).

Transparency and good governance for formalization processes can be stimulated through a participatory approach based on stakeholder communication and involvement in the formalization project (Gunsilius et al., 2011a; Gutberlet, 2012; GIZ, 2010). This has been a success factor in João Pessoa, Diadema and Londrina (Brazil) and Nakuru (Kenya). Active stakeholder involvement was also mentioned in the cases of Iloilo City (Philippines), Dhaka (Bangladesh) and Gianyar (Indonesia), all of which achieved not only a high level of commitment and participation on the part of the public sector, but also active cooperation between recyclers and the government, as well as other stakeholders, such as waste producers. 
With regard to persistent financial and economic barriers, 45\% of the case studies reported at least one financial or economicrelated issue after the implementation of formalization, especially in cities applying formalization approaches 1 and 2 . The case studies reported the lack of financial instruments for supporting formalized waste-workers in investing in their activities. Fluctuating revenues of formalization initiatives based on approaches 1 and 2 may also represent a significant persistent barrier to their financial sustainability. In this case, waste-workers' incomes are very variable and vulnerable due to local recycling market conditions such as prices, demand, and sales volumes (San Vicente de Cañete, Peru; metropolitan Manila, Philippines; Comayahua, Honduras; Mumbai, India), or the lack of business capacities and strategies (MSEs in East Africa: Kenya, Zambia, Tanzania and Uganda). The barriers mentioned existed even before formalization in these cities, being mentioned as very common in the literature on barriers to formalization (Ezeah and Roberts, 2012; Abarca et al., 2013; Troschinetz and Mihelcic, 2009; UN-HABITAT, 2010; Velis et al., 2012). Future formalization initiatives in low-and middle-income countries should thus focus on the inclusion of financial mechanisms for supporting formalized waste-workers, the development of payment schemes, and the strengthening of their business capacities.

Compared with the issue of fluctuating incomes and instability, the alternative of establishing fixed payment schemes seem to be the solution, though this is not always the case. Formalization based on waste collection mostly envisages fixed salaries from waste fees paid by residents. In this case, an unwillingness to pay for waste services may negatively affect the economic stability of formalized waste-workers, representing also an important barrier for formalization projects, as mentioned by Abarca et al., 2013; Cointreau-Levine, 1994; Coffey and Coad, 2010; Ogawa, 1996; and USAID (2014) and as reported in the cases of MSEs in East Africa (Kenya, including Nakura, as well as Zambia, Tanzania and Uganda) and Pune (India).

To address the problem of income instability, some cities have introduced collection and storage centers aimed at increasing sales volumes and enhancing bargaining power regarding fluctuating prices (Medellin and Bogotá, Colombia; Pune, India; Londrina and Diadema, Brazil). This measure may also be combined with a mixed income structure based on fixed waste fees (for collection and other cleaning services) and variable revenues from the sale of recycled materials, as implemented in Londrina and Diadema (Brazil); Iloilo City (Philippines) and Pune (India). This may represent an adequate solution that compensates for the risks of both income schemes and may be used by other countries with similar situations pre-formalization. A low level of willingness to pay can be tackled by reducing waste tariffs for households (Chennai, India), implementing the 'user pay principle (for waste services)' (Nakuru, Kenya; Mumbai, India) or linking waste fees to water or energy supply fees, which is proposed by some studies, such as Lohri et al. (2014) and PAHO (2010). A key factor for designing measures is to formulate them through a consultative process, taking into account the MSWM context.

Although the lack of diversification of products and waste services offered by formalized waste-workers is not expressly mentioned as a strong barrier, some case studies have included several measures in the direction of the diversification of waste services, embedding this as an important aspect of formalization strategies since the development phase. This measure has been included in the Philippines (metropolitan Manila and Iloilo City), Medellin and Bogotá (Colombia), Diadema and Londrina (Brazil), Pune (India), Cairo (Egypt) and Dhaka (Bangladesh), which have all reported positive results, especially in strengthening the financial sustainability of these initiatives. Diversification is also widely recommended in the literature and mentioned as an important success factor for formalization (Velis et al., 2012; Wilson et al., 2009; Scheinberg et al., 2006 and 2010).

Regarding social and behavioral barriers, the assessment identified persistent barriers in $40 \%$ of cases, for instance, the lack of awareness of communities and municipalities regarding their role in MSWM systems, and the positive socioeconomic and environmental impacts of formalized waste management activities (João Pessoa, Brazil; Nakuru, Kenya; San Vicente de Cañete, Peru). There is also a lack of awareness on the formalized waste-workers' side regarding the importance of their jobs, which is reflected in low job satisfaction (Santiago de Surco, Peru) and the lack of commitment on the part of recyclers to stay in their organizations (Mombasa, Kenya). This issue may be due to still existing negative selfperceptions, probably due to the focus of the formalization on victimizing waste-workers, instead empowering them through participatory policies and consultation processes (Scheinberg et al., 2006; Gutberlet, 2011, 2012; Terraza and Sturzenegger, 2010; Gunsilius et al. 2011b; ESCAP, 2015; Scheinberg and Savain, 2015). Furthermore, this may reduce the readiness of informal recyclers to stay in their organization, due to their perception that they would be losing work flexibility and autonomy.

Other reported persistent social barriers are related to the shortcomings of health insurance and pension services (San Vicente de Cañete and Santiago de Surco, Peru; Pune, India; Londrina, Brazil), poor working conditions (Kenya, Zambia, Tanzania and Uganda, East Africa,) and fluctuating incomes for formalized waste-workers that cause economic insecurity and poverty. Regardless of the kind of formalization strategy, decision-makers should redirect their focus from isolated "poverty-alleviation" measures to a policy that integrates socially inclusive measures to policy and financial instruments, taking into account the interactions among categories of interventions or measures (Velis et al., 2012; Scheinberg et al., 2006). The cases of Diadema and Londrina (Brazil), Medellin and Bogotá (Colombia), and Chennai (India) show the good results of a participatory approach, where communication and cooperation among stakeholders, and the high level of community involvement and awareness, have led to a progressive reduction of social issues.

Among the persistent technical barriers (30\% incidence), the lack of capacity and technical skills was the most reported issue (Mumbai, India; Mombasa, Kenya; Iloilo City, Philippines; Dhaka, Bangladesh). Furthermore, problems related to bad infrastructure were reported in the cases of Nakuru (Kenya) and Londrina (Brazil). Also, the lack of data regarding waste composition, quality, material prices and the current situation of informal waste-workers was mentioned as an important barrier in the case of Iloilo City (Philippines).

Compared to persistent barriers in the previous categories, technical barriers are easier to detect and frequently require straightforward solutions specific to the technical context of the MSWM. For instance, some cities have implemented capacitybuilding programs for formalized recyclers aimed at developing and reinforcing technical capacities (Chennai, India; João Pessoa, Brazil). Other cities have focused on the development of capacities for providing diversifying local services and products (Iloilo City, Philippines) or capacity-building for designing strategies based on the decentralization of waste services (Mumbai, India; Nakuru, Kenya).

One limitation of this review was the data collection and assessment of the case studies, based only on secondary sources (papers and reports), which may present out-of-date or incomplete data. As a result, it was not possible to confirm with certainty whether a specific measure was actually applied or not. One way to counteract this was to compare different sources where possible. In the absence of primary data collection, it is recommended to use updated local studies wherever possible. This may help to confirm 
the presence of measures and their effect on the current status of the formalization initiatives. Therefore, further research is required to provide reliable updated evidence of the effectiveness of interventions or measures in enabling formalization in the long term.

\section{Conclusions}

This review was carried out with the aim of orienting policyand decision-makers in the formal sector on the aspects to consider when designing formalization strategies, including the kinds of barriers that need to be removed and the enabling measures that increase the chances of successful formalization in the long term. The review concludes that the lack of interventions in any categories of barriers may lead formalization initiatives to fail, thus making barriers 'persistent' even after formalization has been implemented. Furthermore, it concludes that 'persistent barriers' may also appear due to the lack of awareness of policy- and decision-makers concerning the close interaction between interventions or measures.

Finally, no conclusion is possible regarding which formalization approach has the greatest chance of success in the long term. Nevertheless, the inclusion of country-appropriate measures at the policy, economic and institutional levels represents a key factor in formalization strategies, increasing the chances of success. Moreover, the empowerment of formalized waste-workers is again confirmed as a further key success factor, though it is influenced by how governments design policies and strategies for the sector that acknowledge the contribution of formalized recyclers and view them as relevant stakeholders in their waste management systems. Further research is needed regarding the impacts of the enabling measures on the current status of formalization experiences, especially their inclusion in policies and national MSWM strategies.

\section{Appendix A. Supplementary material}

Supplementary data associated with this article can be found, in the online version, at http://dx.doi.org/10.1016/j.wasman.2016.12. 028.

\section{References}

Abarca, L., Maas, G., Hogland, W., 2013. Review: solid waste management challenges for cities in developing countries. Waste Manage. 33, 220-232. http://dx.doi.org/10.1016/j.wasman.2012.09.008.

Aparcana, S., Salhofer, S., 2013. Development of a social impact assessment methodology for recycling systems in low income countries. Int. J. Life Cycle Assess. 18 (5), 1106-1115. http://dx.doi.org/10.1007/s11367-013-0546-8.

Aparcana, S., Linzner, R., Salhofer, S., 2012. Social assessment of recycling systems Peruvian case studies. Proceed. ICE - Waste Resour. Manage. 166 (2), 84-92. http://dx.doi.org/10.1680/warm.12.00008.

Baud, I., Grafakos, S., Hordijk, M., Post, J., 2001. Quality of life and alliances in solid waste management. Contributions to urban sustainable development. J. Cities 18 (1), 3-12. http://dx.doi.org/10.1016/S0264-2751(00)00049-4. <http://www. iacenter.ir/uploads/Quality_of_Life_and_Alliances_in.pdf> (accessed 15.11.2015).

Bennagen, E., Nepomuceno, G., Covar, R., 2002. Solid waste segregation and recycling in Metro Manila: household attitudes and behavior. Resources, Environment \& Economics Center for Studies (REECS), Manila, Philippines. $<$ https://idl-bnc.idrc.ca/dspace/bitstream/10625/32393/3/118095.pdf> (accessed 10.03.2016)

Burcea, S., 2015. Formalizing the Romanian informal waste sector: how Interested are informal recyclers? Bucharest University of Economic Studies, Romania. In: 15th International Academic Conference, Rome. http://dx.doi.org/10.20472/IAC. 2015.015.037. <https://ideas.repec.org/p/sek/iacpro/1003738.html> (accessed 11.07.2016)

Chikarmane, P., 2012. Integrating Waste Pickers into Municipal Solid Waste Management in Pune, India WIEGO Policy Brief (Urban Policies) No 8 July 2012. <http://www.inclusivecities.org/wp-content/uploads/2012/10/Chikarmane_ WIEGO_PB8.pdf> (accessed 14.11.2015).

Cleary, J., 2009. Life cycle assessments of municipal solid waste management systems: a comparative analysis of selected peer-reviewed literature. Environ. Int. 35, 1256-1266.

Coffey, M., Coad, A., 2010. Collection of Municipal Solid Waste in Developing Countries. United Nations Human Settlements Programme (UN-HABITAT).
ISBN: (Volume) 978-92-1-132254-5. <http://mirror.unhabitat.org/pmss/ listItemDetails.aspx?publicationID $=3072>$ (accessed 10.03.2016)

Cointreau, S., 2006. Occupational and environmental health issues of solid waste management. Special Emphasis on Middle- and Lower-income Countries. Urban Papers. Urban sector board. The World Bank Group. Washington D.C. <http://siteresources.worldbank.org/INTUSWM/Resources/up-2.pdf> (accessed 09.11.2014).

Cointreau-Levine, S., 1994. Private Sector Participation in Municipal Solid Waste Services in Developing Countries. Volume 1. The Formal Sector. UNDP/UNCHS/ World Bank Urban Management Programme. ISSN: 1020-0215. <http://www ilo.org/wcmsp5/groups/public/@ed_emp/@emp_policy/@invest/documents/ projectdocumentation/wcms asist 8263.pdf> (accessed 31.03.2016).

DANIDA - PREMACA, 2012. Green Growth in Practice Lessons Learnt from promoting Eco-Enterprises in Honduras and Guatemala <http://um.dk/en/ $\sim$ media/UM/English-site/Documents/Danida/Partners/Research-Org/Researchstudies/Green\%20Growth\%20in\%20Praksis\%202012.pdf> (accessed 17.12.2015).

Dias Sonia, 2010. Overview of the legal framework for social inclusion in solid waste management in brazil by sonia dias, wiego waste sector specialist. <http:// globalrec.org/wp-content/uploads/2014/03/overview-of-the-legal-frameworkfor-social-inclusion-.pdf> (accessed 07.07.2016).

Economic and Social Commission for Asia and the Pacific - ESCAP, 2015. Valuing Waste, Transforming Cities. <http://www.unescap.org/sites/default/files/Full\% 20Report\%20\%20.pdf> (accessed 07.07.2016).

Ezeah, Ch., Roberts, C., 2012. Analysis of barriers and success factors affecting the adoption of sustainable management of municipal solid waste in Nigeria. J. Environ. Manage. 103, 9-14. http://dx.doi.org/10.1016/j.jenvman.2012.02.027.

Ezeah, C., Fazakerley, J., Roberts, C., 2013. Emerging trends in informal sector recycling in developing and transition countries. Waste Manage. 33 (11), 25092519. http://dx.doi.org/10.1016/j.wasman.2013.06.020.

Deutsche Gesellschaft für Internationale Zusammenarbeit (GIZ), 2010. The Waste Experts: Enabling Conditions for Informal Sector Integration in SWM (GIZ) <https://www.giz.de/de/downloads/gtz2010-waste-experts-conditionsis-integration.pdf> (accessed 12.11.2015).

Deutsche Gesellschaft fur Internationale Zusammenarbeit - GIZ (No date) Vertically Integrated Nationally Appropriate Mitigation Actions (V-NAMAs): Policy Recommendations, Case Studies and Tools for the Integration of Sub-national Actors in National Mitigation Actions. <http://star-www.giz.de/cgi-bin/starfetch. exe?ehXR426vcNiPgOTBbv3BnQe2XxwDFgXR2yY.@Kr6gBqFuw9i2GgVJU5wzl 7xYnTKUSGIntxdnjTZQxatBiwGpp.GWrmQGrPi7TJ8ISr.Yv1ti.ljLC1.71qC0dMug 20tjWSVpZ5cBqauBTRaNl2eIRVIO85azleuyGUzBQNs9k8/giz2014-1771envertically-mitigation_actions.pdf> (accessed 11.07.2016).

Gunsilius, E., Spies, S., García-Cortés, S., Medina, M., Dias, S., Scheinberg, A., Sabry, W., Abdel-Hady, N., Florisbela dos Santos, A., Ruiz, S., 2011-a. Recovering resources, creating opportunities Integrating the informal sector into solid waste management. Deutsche Gesellschaft für Internationale Zusammenarbeit (GIZ) <https://www.giz.de/de/downloads/giz2011-en-recycling-partnershipsinformal-sector-final-report.pdf $>$ (accessed 09.11.2015).

Gunsilius E, Chaturvedi B, Scheinberg A (2011-b) The Economics of the informal sector in Solid Waste Management. GIZ - the Deutsche Gesellschaft für Internationale Zusammenarbeit GmbH. https://www.giz.de/de/downloads/ giz2011-cwg-booklet-economicaspects.pdf. Accessed 06.07.2016.

Gutberlet, J., 2011. Waste to energy, wasting resources and livelihoods. Integr Waste Manage. 1, 219-236. http://dx.doi.org/10.5772/17195. <http://cdn. intechopen.com/pdfs-wm/17438.pdf> (accessed 18.09.2015).

Gutberlet, J., 2012. Informal and cooperative recycling as a poverty eradication strategy. Department of Geography, University of Victoria. Geogr. Compass 6 (1), 19-34. http://dx.doi.org/10.1111/j.1749-8198.2011.00468.x.

Hoornweg, D., Bhada-Tata, P., 2012. WHAT A WASTE: A Global Review of Solid Waste Management. The World Bank. March 2012, No. 15. <http://siteresources. worldbank.org/INTURBANDEVELOPMENT/Resources/336387-1334852610766/ What a Waste2012_Final.pdf> (accessed 10.11.2014).

International Labour Organisation - ILO, 2004. Addressing the Exploitation of Children in Scavenging (Waste Picking): a Thematic Evaluation on Action on Child Labour. ISBN PDF: 92-2-116662-7. <http://www.bvsde.paho.org/bvsacd/ cd27/scavenging.pdf> (accessed 11.12.2014).

Informal Waste Pickers and Recyclers - IWPAR, No date. For the social inclusion and protection of impoverished waste pickers and recyclers. Good practices \#14, Waste Concern, Bangladesh. <http://iwpar.org/pdf/best_practices/Best_ Practice_14_Bangladesh.pdf> (accessed 19.07.2016).

Kashyap, P., Visvanathan, Ch., 2014. Municipal Solid Waste Management in Asia and the Pacific. Challenges and strategic solutions. In: Pariatamby, Agamuthu, Tanaka, Masaru (Eds.), Book.: Environmental Science. Springer. ISBN 978-9814451-73-4.

Katusiimeh, M., Burger, K., Mol, A., 2013. Informal waste collection and its coexistence with the formal waste sector: the case of Kampala, Uganda. Habitat Int. 38. http://dx.doi.org/10.1016/j.habitatint.2012.09.002.

Kuria, D., Muasya, R., 2010. Mapping of Waste Pickers and Organizations Supporting Waste Pickers in Kenya. Women in Informal Employment: Globalizing and Organizing (WIEGO). <http://wiego.org/sites/wiego.org/files/publications/files/ Kuria_Muasya_Mapping_WP_Kenya.pdf $>$ (accessed 31.11.2015).

Law $\mathrm{N}^{\circ} 29419,2009$. Ley que regula la actividad de los recicladores. (Law for regulation of the recyclers' activities). <http://wiego.org/sites/wiego.org/files/ resources/files/Lima-Ley-Recicladores.pdf> (accessed 11.07.2016).

Linzer, R., Salhofer, S., 2014. Municipal solid waste recycling and the significance of informal sector in urban China. Waste Manage. Res. 32 (9), 896-907. http://dx doi.org/10.1177/0734242X14543555. 
Linzner, R., Lange, U., 2013. Role and size of informal sector in waste management a review. Waste Resour. Manage. - ICE Proceed. 166 (2), 69-83. ISSN 1747-6526.

Lohri, C., Camenzind, E., Zurbrügg, C., 2014. Financial sustainability in municipal solid waste management - costs and revenues in Bahir Dar, Ethiopia. Waste Manage. 34, 542-552. http://dx.doi.org/10.1016/j.wasman.2013.10.014.

Mahadevia, D., Pharate, B., Mistry, A., 2005. New practices of waste management case of Mumbai, working paper $\mathrm{N}^{\circ} 35$. School of Planning, Center for Environmental Planning and Technology CEPT University Kasturbhai Lalbhai, India. <http://wiego.org/publications/new-practices-waste-management-casemumbai> (accessed 18.04.2015).

Marello, M., Helwege, A., 2014. Solid Waste Management and Social Inclusion of Waste Pickers: Opportunities and Challenges GEGI working paper, The Frederik S. Pardee Center for the study of the longer - range future, Center for Finance, Law and Policy, University of Boston, paper 7. <https://www.bu.edu/ pardeeschool/files/2014/11/Social-Inclusion-Working-Paper.pdf> (accessed 07.07.2016).

Medina, M., 2000. Scavenger cooperatives in Asia and Latin America. Resour Conserv. Recycl. 31, 51-89. http://dx.doi.org/10.1016/S0921-3449(00)00071-9.

Mwanzia, P., Kimani, S.N., Stevens, L., 2013. Integrated solid waste management: Decentralised service delivery case study of Nakuru municipality, Kenya. In: 36th WEDC International Conference, Nakuru, Kenya. Briefing paper 1812 <practicalaction.org/media/download/30740> (accessed 17.03.2015).

Nas, P., Jaffe, R., 2004. Informal waste management. Shifting the focus from problem to potential. Environ. Dev. Sustain. 6, 337-353. <http://www.fishecology.ch/ sandec/publikationen/swm/dl/informal_Waste_Management.pdf> (accessed 17.11.2014).

Ogawa, H., 1996. Sustainable Solid Waste Management in Developing Countries. In: WHO Western Pacific Regional Environmental Health Centre (EHC), 7th ISWA International Congress and Exhibition, Parallel Session 7, 'International Perspective'. <http://www.gdrc.org/uem/waste/swm-fogawa1.htm>. (accessed on 13.11.2014)

Pan American health Organisation (PAHO), 2010. Inter-American Association of Sanitary and Environmental Engineering (AIDIS), Inter-American development Bank (IDB). Regional Evaluation on Urban Solid Waste Management in Latin America and The Caribbean. <http://idbdocs.iadb.org/wsdocs/getdocument. aspx?docnum=36846537> (accessed 15.07.2016).

Parizeau, K., 2011. Urban Dirty Work: Labor Strategies, Environmental Health, and Coping Among Informal Recyclers in Buenos Aires, Argentina. Graduate Department of Geography, University of Toronto. <https://tspace.library. utoronto.ca/handle/1807/29836> (accessed 11.04.2016).

Paul, J.G., Arce-Jaque, J., Ravena, N., Villamor, S.P., 2012. Integration of the informal sector into municipal solid waste management in the Philippines -What does it need? Waste Manage. 32 (11), 2018-2028. http://dx.doi.org/10.1016/j. wasman.2012.05.026.

Moroccan National Waste Management Plan (PNDM), 2007. <http://www environnement.gov.ma/fr/dechets?id=226> (accessed 11.07.2016).

Premakumara, D.G.J., 2012. Kitakyushu City's International Cooperation for Organic Waste Management in Surabaya City, Indonesia and Its Replication in Asian Cities. <http://pub.iges.or.jp/modules/envirolib/upload/3597/attach/Surabaya\% 5BEnglish\%5D.pdf> (accessed 13.07.2016).

Rathi, S., 2006. Alternative approaches for better municipal solid waste management in Mumbai. India. Waste Manage. 26 (10), 1192-1200. http://dx. doi.org/10.1016/j.wasman.2005.09.006.

RECUPERAR web site, No date. Asociacion de recicladores, Medellin, Colombia. (Recyclers Association RECUPERAR, Medellin, Colombia), <http://www. recuperar.com.co> (accessed 16.11.2015).

Rushton, L., 2003. Health hazards and waste management. MRC Institute for Environment and Health, Leicester, UK. Br. Med. Bull. 68, 183-197. http://bmb. oxfordjournals.org/. Accessed 15.10.2015.

SANDEC Report, 1996. Non-governmental refuse collection in Low income Urban areas. Lessons learned from selected schemes in Asia, Africa, and Latin America, vol. 1/96. <http://www.ircwash.org/resources/non-governmentalrefuse-collection-low-income-urban-areas-lessons-learned-selected-schemes> (accessed 14.07.2015).

Sang-Arun, J., Bengtsson, M., Wanpen, P., Li, J., Modak, P., Chong Theng, L., 2014. Final Report: Promoting recycling in municipal solid waste management through suitable business models: Improving the supply chain for recyclables. Sustainable Consumption and Production Area, Institute for Global Environmental Strategies. <https://prasadmodakblog.files.wordpress.com/ 2014/08/final_report_recycling_business_final-july28-2014.pdf> (accessed 13.07.2016).

Scheinberg, A., Savain, R., 2015. Valuing Informal Integration: Inclusive Recycling in North Africa and the Middle East. Eschborn, Germany, Deutsche Gesellschaft fü Internationale Zusammenarbeit (GIZ) GmbH. <http://wiego.org/publications valuing-informal-integration-inclusive-recycling-north-africa-and-middle-east> (accessed 08.07.2016)

Scheinberg, A., Anschütz, J., Van de Klundert, A., 2006. Waste pickers: poor victims or waste management professionals? Workshop: Solid waste, health and the millennium development goals. Collaborative working group on solid waste management in low- and middle-income countries (CWG). Paper 56.Kolkata, India.

Scheinberg, A., Simpson, M., Gupt, Y., Anschütz, Y., Haenen, I., Tasheva, E., Hecke, J. Soos, R., Chaturvedi, B., Garcia-Cortes, S., Gunsilius, E., 2010. Economic Aspects of the Informal Sector in Solid Waste Management. GTZ (German Technica Cooperation), Eschborn, Germany. <http://www2.gtz.de/dokumente/bib-2011/ giz2011-0116en-informal-sector-solid-waste-management.pdf> 15.07.2016)

Schmied, E., Scherhaufer, S., Obersteiner, G., Kabosch, U., Kobler, A., Stix, S., 2011 Formalisation options for informal sector activities and their legal requirements in Central Europe. Paper delivered at the Thirteenth International Waste Management and Landfill Symposium, Sardinia 2011. Vienna, Austria BOKU, Institute of Waste Management, University of Natural Resources and Life, Sciences.

Sinha, M., 2012. Emission Reduction Through Composting of Organic Waste in Dhaka, Dhaka, Bangladesh. International Symposium "Cities in a Changing Climate“, Frankfurt am Main. <https://www.kfw-entwicklungsbank.de/ migration/Entwicklungsbank-Startseite/Development-Finance/Sectors/UrbanDevelopment/Events/Cities-in-a-Changing-Climate/Presentation-held-by-MrMaqsood-Sinha.pdf> (accessed 19.07.2016).

Terraza, H., Sturzenegger, G., 2010. Dinámicas de organización de los recicladores informales. Tres casos de estudio en América Latina. Sector de infraestructura y medio ambiente. Nota técnica $\mathrm{N}^{\circ} 117$. (Organization dynamics of informal recyclers. Three case studies from Latin America. Infrastructure and environment sector. Technical note $\mathrm{N}^{\circ}$ 117). Inter - American Development Bank, 2010. <http://idbdocs.iadb.org/wsdocs/getdocument.aspx?docnum= 35325785> (accessed 09.09.2015)

Troschinetz, A., Mihelcic, J., 2009. Sustainable recycling of municipal solid waste in developing countries. Waste Manage. 29 (2), 915-923. http://dx.doi.org/ 10.1016/j.wasman.2008.04.016.

United Nations Environment Programme (UNEP), 2005. Solid waste management. International Environmental Technology Centre (IETC), vol. 1, part 4, appendix A. <http://www.unep.org/ietc/InformationResources/Publications/SolidWasteManagementPublication/tabid/79356/Default.aspx\#WastePubTop> (accessed 27.10.2014).

United Nations Environmental Programme (UNEP), 2010. Waste and Climate Change: Global trends and strategy framework. Division of Technology, Industry and Economics, International Environmental Technology Centre Osaka/Shiga. <http://www.unep.or.jp/ietc/Publications/spc/Waste\&ClimateChange/Waste\&ClimateChange.pdf> (accessed on 10.11.2014).

UNESCO (no date). Community Participation for Clean Surroundings - EXNORA Best Practices for Human Settlements, MOST Clearing House Best Practices Database. <http://www.unesco.org/most/asia3.htm> (accessed 14.11.2015).

UN - HABITAT, 1998. Best practices award. 'Linis Ganda' Program for the household waste recycling in Metro, Manila, 1998, <http://habitat.aq.upm.es/dubai/98/ bp602.html> (accessed 12.11.2015).

UN - HABITAT, 2004. Best Practices award. Latin America and Caribbean. Integrated waste management project, Joao Pessoa, Brasil, 2004, <http://habitat.aq.upm. es/bpal/onu04/bp2562.html> (accessed 24.11.2015).

UN - HABITAT, 2010. Solid waste management in the world's cities. Water and sanitation in the world's cities, United Nation Human Settlements Program, London. <http://www.sswm.info/sites/default/files/reference_attachments/ UN\%20HABITAT\%202010\%20Solid\%20Waste\%20Management\%20in\%20the\%20 Worlds\%20Cities.pdf> (accessed 31.03.2016).

United States Agency for International Development (USAID), 2014. Solid Waste: Generation, Handling, Treatment, and Disposal. Sector Environmental Guidelines. <http://www.usaidgems.org/Documents/SectorGuidelines/SectorEnvironmentalGuidelines_SolidWasteGuidelines_2014.pdf > (accessed 15.07.2016).

Velis, C., Wilson, D., Rocca, O., Smith, S., Mavropoulos, A., Cheeseman, C., 2012. An analytical framework and tool ('InteRa') for integrating the informal recycling sector in waste and resource management systems in developing countries. Waste Manage. Res. 30 (9), 43-66. http://dx.doi.org/10.1177/0734242X12 454934.

WASTE, 2001. Community Partnerships in Integrated Sustainable Waste Management. Tools for Decision-makers. Experiences from the Urban Waste Expertise Programme. <http://www.waste.nl/sites/waste.nl/files/product/files/ tools compart.pdf> (accessed 30.10.2015).

Wang, X., Geng, Y., 2012. Municipal solid waste management in Dalian: practices and challenges. Front. Environ. Sci. Eng. 6 (4), 540-548. http://dx.doi.org/ 10.1007/s11783-011-0361-z

WIEGO, 2009. Refusing to be Cast Aside: Waste Pickers Organising Around the World <http://wiego.org/sites/wiego.org/files/publications/files/SamsonRefusing-to-be-Cast-Aside-Wastepickers-Wiego-publication-English.pdf> (accessed 30.10.2015)

Wilson, D., Velis, C., Cheeseman, C., 2006. Role of informal sector recycling in waste management in developing countries. Habitat Int. 30 (4), 797-808. http://dx. doi.org/10.1016/j.habitatint.2005.09.005.

Wilson, D., Araba, A., Chinwah, K., Cheeseman, C., 2009. Building recycling rates through the informal sector. Waste Manage. 29 (2), 629-635. http://dx.doi.org/ 10.1016/j.wasman.2008.06.016.

Wilson, D., Rodic, L., Scheinberg, A., Velis, C., Alabaster, G., 2012. Comparative analysis of solid waste management in 20 cities. Waste Manage. Res. 30 (3), 237-254. http://dx.doi.org/10.1177/0734242X12437569.

Yates, J., Gutberlet, J., 2011. Enhancing livelihoods and the urban environment: the local political framework for integrated organic waste management in Diadema, Brazil. J. Develop. Stud. 47 (4), 439-456. http://dx.doi.org/10.1080/ 00220388.2010.506914.

Zurbrügg, C., Gfrerer, M., Ashadi, H., Brenner, W., Küper, D., 2012. Determinants of sustainability in solid waste management - the Gianyar Waste Recovery Project in Indonesia. Waste Manage. 32 (11), 2126-2133. http://dx.doi.org/10.1016/j. wasman.2012.01.011. 